\title{
ОЦІНКА БІОХІМІЧНИХ ПОКАЗНИКІВ І СТАНУ ЗГОРТАЛЬНОЇ СИСТЕМИ КРОВІ ЩУРІВ ЗА УМОВ ХРОНІЧНОЇ НЕОПЛАСТИЧНОЇ ІНТОКСИКАЦІЇ
}

Вступ. Онкологічні хворі належать до групи високого ризику розвитку тромбоемболічних та інших тяжких ускладнень, що можна пояснити прогресуванням пухлини і дією цитостатичних препаратів через порушення як біохімічних, так і гемостазіологічних процесів. Особливе значення при цьому має ендогенна інтоксикація організму.

Мета дослідження - оцінити біохімічні показники і стан згортальної системи крові щурів за умов хронічної неопластичної інтоксикації.

Методи дослідження. Експеримент виконано на 36-ти статевозрілих нелінійних щурах. Хронічну неопластичну інтоксикацію моделювали шляхом введення несиметричного 1,2-диметилгідразин гідрохлориду (ДМГ) підшкірно в міжлопаткову ділянку в дозі 7,2 мг/ке 1 раз на тиждень упродовж 30-ти тижнів, відповідно до маси тварини - з розрахунку 0,1 мл розчину ДМГ на 10 г маси тіла щура. Дослідження гемостазіологічного стану плазми крові включало визначення протромбінового часу за Квіком, протромбінового індексу, активованого часткового тромбопластинового часу, фрібриногену А та фрібрин-мономерного комплексу.

Результати й обговорення. Згідно з результатами аналізу біохімічних показників пероксидного окиснення ліпідів і антиоксидантного захисту, на 70-й день експерименту відмічено лише тенденцію до їх зростання порівняно з контрольними даними. На 140-й та 210-й дні виявлено достовірне їх підвищення щодо контрольної групи. Визначення вмісту в сироватці крові щурів молекул середньої маси фрракцій, що визначались при довжині хвилі 254 і 280 нм, у різні терміни спостереження показало статистично достовірне збільшення. Відмічено несуттєве зростання активованого часткового протромбінового часу протягом усього експерименту. Відносно інших показників зареєстровано хвилеподібні зміни гемостазіологічних показників.

Висновки. Протягом 210-ти днів експерименту наростають прояви ендогенної інтоксикації, про що свідчить достовірне підвищення рівня в крові молекул середньої маси. Надмірне утворення продуктів вільнорадикального окиснення в поєднанні з компенсаторною активацією ензимних ланок антиоксидантної системи в початковий період експерименту і поступовим ії виснаженням, починаючи із 140-го дня, підтверджується достовірним зниженням активності супероксиддисмутази і каталази в сироватці крові до кінця експерименту стосовно контролю. Подовження протромбінового часу, скорочення протромбінового індексу, зростання в крові рівня фрібриногену А та розчинного фрібрин-мономерного комплексу можна розцінювати як передумову патофрізіологічного обірунтування фрактора ризику активації згортання крові в онкологічних хворих.

КЛЮЧОВІ СЛОВА: експериментальна хронічна неопластична інтоксикація; пероксидне окиснення ліпідів; ендогенна інтоксикація; згортальна система крові.

ВСТУП. За даними сучасної літератури, онкологічні хворі належать до групи високого ризику розвитку тромбоемболічних та інших тяжких ускладнень, що можна пояснити прогресуванням пухлини і дією цитостатичних препаратів через порушення як біохімічних, так і гемостазіологічних процесів [1-5]. Ініціальним фрактором активації гіперкоагуляції в них вважають експресію тканинного фрактора [6]. Водночас у ряді робіт розкривається роль схильності до тромбоутворення в онкологічних хворих, так (ㄱ. Я. Боднар, Н. Є. Лісничук, 2019. званого ракового прокоагулянта, який активує $\mathrm{X}$ і XIII фрактори [7-10]. Особливе значення при цьому має ендогенна інтоксикація організму, оскільки цитокіни, фрактор некрозу пухлини та інтерлейкін 1 суттєво збільшують продукцію тканинного фрактора, що також сприяє активації тромбоутворення [7]. Окрім того, цитокіни ушкоджують ендотелій, що зумовлює посилення прокоагулянтної і пригнічення антикоагулянтної та фрібринолітичної їх функцій і сприяє тромбоутворенню [8]. Таким чином, короткий аналіз літератури засвідчує єдність порушень біохіміч- 
них і гемостазіологічних процесів у онкологічних хворих. Вивчення в експерименті біохімічних та реологічних показників крові за умов хронічної неопластичної інтоксикації, а також дії цитостатичних препаратів дасть змогу уточнити і доповнити клінічну важливість проблеми тромбоемболічних ускладнень у хворих на рак.

Мета дослідження - оцінити біохімічні показники і стан згортальної системи крові щурів за умов хронічної неопластичної інтоксикації.

МЕТОДИ ДОСЛІДЖЕННЯ. Експеримент виконано на 36-ти статевозрілих нелінійних щурах-самцях масою 170-180 г. Тварин утримували на збалансованому стандартному раціоні віварію Тернопільського національного медичного унісерситету імені І. Я. Горбачевського МО3 України. Моделювали патологічні процеси і виводили щурів 3 досліду згідно з принципами біоетики, правилами належної лабораторної практики (GLP), а також етичними нормами, викладеними в положеннях Європейської конвенції про захист хребетних тварин, що використовуються для дослідних та інших наукових цілей, та відповідно до Науково-практичних рекомендацій з утримання лабораторних тварин та роботи $з$ ними $[11,12]$.

Хронічну неопластичну інтоксикацію моделювали шляхом введення несиметричного 1,2-диметилгідразин гідрохлориду (ДМГ) (фрірми "SIGMA-ALDRICH CHEMIE", виробництва Японії, серії D161802), попередньо розведеного ізотонічним розчином натрію хлориду. Канцероген вводили підшкірно в міжлопаткову ділянку в дозі 7,2 мг/кг (з розрахунку на діючу речовину) 1 раз на тиждень упродовж 30-ти тижнів, відповідно до маси тварини - 3 розрахунку 0,1 мл розчину ДМг на 10 г маси тіла щура [13]. Летальність становила 11 \%. Протягом 30-го тижня експерименту загинули 4 тварини. Контролем для основної експериментальної групи тварин, яким вводили ДМГ, були 12 щурів, яким щотижня підшкірно вводили 0,1 мл фрізіологічного розчину на 10 г маси тіла. 3 біохімічних показників крові визначали рівень дієнових (ДК) та триєнових кон'югатів (ТК) $[14,15]$, середньомолекулярних пептидів (молекул середньої маси фрракцій, що визначались при довжині хвилі 254 і 280 нм, $\mathrm{MCM}_{254}$ та $\mathrm{MCM}_{280}$ ) [16, 17], ТБК-активних продуктів (ТБК-АП), активність супероксиддисмутази (СОД) і каталази (КАТ) [18-20]. Дослідження гемостазіологічного стану плазми крові включало визначення протромбінового часу за Квіком, протромбінового індексу, активованого часткового тромбопластинового часу, фрібриногену А та розчинного фрібрин-мономерного комплексу згідно з інструкцією до реактивів фрірми "RENAM" (Німеччина).

РЕЗУЛЬТАТИ Й ОБГОВОРЕННЯ. ЗГіДНО 3 результатами аналізу біохімічних показників пероксидного окиснення ліпідів (табл. 1), на 70-й день експерименту відмічено лише тенденцію до їх зростання порівняно 3 контрольними даними. Так, активність ДК зросла на 1,83 \%, ТК - на 0,8 \%, вміст ТБК-АП збільшився на 1,94 \%.

На відміну від даних, отриманих на 70-й день, на 140-й день відмічали достовірне підвищення активності ДК на 35,8 \%, ТК - на 40,8 \%, рівня ТБК-АП - на 33,6 \% відносно контролю.

На 210-й день досліджувані показники пероксидного окиснення ліпідів достовірно зростали щодо контрольної групи: активність ДК підвищилася на $111 \%$, ТК - на 87,2 \%, рівень ТБК-АП збільшився на 63,6 \% порівняно 3 даними контрольної групи, що вказувало на активацію процесу пероксидного окиснення.

Що стосується основних ензимів антиоксидантного захисту, то отримані результати (табл. 1) свідчать про те, що рівень СОД у крові на 70-й день неопластичної інтоксикації практично не відрізнявся від контрольного показника, проте на 140-й день зафріксовано достовірно високе значення цього ензиму, яке було більшим на 8,2 \% від даних, отриманих на 70-й день. Загалом протягом останніх термінів спостереження (140-й і 210-й дні) зміна активності СОД мала коливальний характер, і до кінця експери-

Таблиця 1 - Показники пероксидного окиснення ліпідів і антиоксидантного захисту в сироватці крові при синдромі неопластичної інтоксикації (Mm)

\begin{tabular}{|c|c|c|c|c|c|c|c|}
\hline $\begin{array}{c}\text { Тривалість } \\
\text { експери- } \\
\text { менту, дні }\end{array}$ & $\begin{array}{c}\text { ДК, } \\
\text { ммоль/л }\end{array}$ & $\begin{array}{c}\text { ТК, } \\
\text { ммоль/л }\end{array}$ & $\begin{array}{l}\text { ТБК-АП, } \\
\text { ммоль/л }\end{array}$ & $\begin{array}{l}\text { СОД, } \\
\text { ум. од. }\end{array}$ & $\begin{array}{c}\text { КАТ, } \\
\text { мкат/л }\end{array}$ & $\mathrm{MCM}_{254}$ & $\mathrm{MCM}_{280}$ \\
\hline $\begin{array}{l}\text { Контроль } \\
(\mathrm{n}=12)\end{array}$ & $1,09 \pm 0,08$ & $1,25 \pm 0,09$ & $3,60 \pm 0,04$ & $48,15 \pm 0,67$ & $43,02 \pm 1,03$ & $0,022 \pm 0,001$ & $0,019 \pm 0,001$ \\
\hline $70(n=12)$ & & & & & $43,94 \pm 1,02$ & $0,024 \pm 0,001^{*}$ & $0,025 \pm 0$ \\
\hline $140(n=12)$ & $1,48 \pm 0,0$ & $1,76 \pm 0,12^{\star \star}$ & $4,81 \pm$ & $52,12 \pm 0,60 *$ & $49,02 \pm 1,02^{\star *}$ & $0,026 \pm 0,001^{\star *}$ & 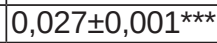 \\
\hline $210(n=8)$ & $2,30 \pm 0,07^{\star \star \star}$ & $2,34 \pm 0,09 * * \star$ & $5,89 \pm 0,13^{\star \star \star}$ & $43,51 \pm 1,02^{*}$ & $45,80 \pm 0,91^{*}$ & 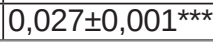 & 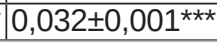 \\
\hline
\end{tabular}

Примітка. Тут і в таблиці 2: * - величини, які статистично достовірно відрізняються від аналогічних показників у тварин контрольної групи за критерієм Брауна - Форсайта (* $\left.-p<0,05 ;{ }^{*}-p<0,01 ;{ }^{* \star}-p<0,001\right)$. 
менту вона знизилась на 16,5 \% відповідно до максимального зростання і на 9,6 \% відносно контролю.

Аналогічні дані отримано стосовно іншої ензимної ланки системи антиоксидантного захисту - каталази. Як свідчать дані, наведені в таблиці 1, на 70-й день від початку експерименту її активність у сироватці крові мала тенденцію до зростання, проте достовірно не відрізнялась від контролю, на 140-й день відзначено достовірне підвищення активності КАТ на 11,6 \% щодо 70-го дня і тенденцію до зниження на 210-й день порівняно з попереднім терміном.

Згідно з отриманими даними, вміст $\mathrm{MCM}_{254}$ у сироватці крові щурів у різні терміни спостереження достовірно ( $<<0,001)$ збільшився. Так, на 70-й день показник зріс на 10,4 \% відносно конт-

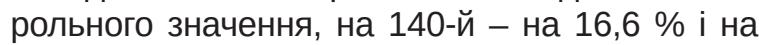
210-й - на 20,5 \% відповідно. Потрібно відмітити, що вказані цифррові величини статистично достовірно відрізнялись між собою.
Визначення вмісту $\mathrm{MCM}_{280}$ показало, що їх рівень достовірно зростав у всі терміни спостереження і був найвищим на 210-ту добу, тобто на 68,2 \% відносно контролю ( $<<0,001)$.

Отримані результати стосовно динаміки гемостазіологічних показників плазми крові характеризувалися неоднозначністю їх активності відносно терміну експерименту (табл. 2).

Відмічено несуттєве $(p<0,05)$ збільшення активованого часткового протромбінового часу протягом усього експерименту (табл. 2). Відносно інших показників зареєстровано хвилеподібні зміни гемостазіологічних показників. Так, зареєстровано зростання на 70,9 \% кількості фрібриногену А на 140-й день порівняно $з$ контролем, а також розчинного фрібрин-мономерного комплексу на 30,7 \% на 140-й день і зниження на 15,9\% на 210-й день порівняно $з$ показниками на 140-й день. Таким чином, 140-й день можна вважати найбільш уразливим терміном стосовно ризику згортання крові.

Таблиця 2 - Гемостазіологічні показники крові при синдромі неопластичної інтоксикації (M士m)

\begin{tabular}{|l|c|c|c|c|}
\hline \multirow{2}{*}{\multicolumn{1}{|c|}{ Показник }} & \multicolumn{3}{|c|}{ Термін експерименту, дні } \\
\cline { 2 - 5 } & контроль $(\mathrm{n}=12)$ & $70(\mathrm{n}=12)$ & $140(\mathrm{n}=12)$ & $210(\mathrm{n}=8)$ \\
\hline Протромбіновий час, с & $16,12 \pm 0,15$ & $19,02 \pm 0,49^{\star}$ & $22,36 \pm 0,72^{\star \star \star}$ & $17,32 \pm 0,17^{\star}$ \\
\hline Протромбіновий індекс, \% & $95,47 \pm 0,19$ & $98,23 \pm 0,87$ & $78,89 \pm 0,56^{\star \star \star}$ & $82,67 \pm 0,54^{\star}$ \\
\hline $\begin{array}{l}\text { Активований частковий } \\
\text { тромбопластиновий час, с }\end{array}$ & $17,24 \pm 0,45$ & $19,67 \pm 0,45^{\star}$ & $19,12 \pm 0,06^{*}$ & $19,89 \pm 0,74^{*}$ \\
\hline Фібриноген А, г/л & $3,37 \pm 3,66$ & $4,89 \pm 0,75^{\star}$ & $5,76 \pm 0,34^{\star \star \star}$ & $4,98 \pm 0,32^{\star \star}$ \\
\hline $\begin{array}{l}\text { Розчинний фрібрин-моно- } \\
\text { мерний комплекс, 10² г/л }\end{array}$ & $1,01 \pm 0,02$ & $1,20 \pm 0,41^{\star \star}$ & $1,32 \pm 0,04^{\star \star \star}$ & $1,11 \pm 0,23^{\star}$ \\
\hline
\end{tabular}

ВИСНОВКИ. 1. Протягом 210-ти днів експериментальної неопластичної інтоксикації наростають прояви ендогенної інтоксикації, про що свідчить достовірне $(p<0,001)$ підвищення рівня в крові молекул середньої маси.

2. У сироватці крові щурів за умови синдрому неопластичної інтоксикації спостерігають поступове надмірне утворення продуктів вільнорадикального окиснення в поєднанні 3 компенсаторною активацією ензимних ланок антиоксидантної системи в початковий період експерименту і поступовим їі виснаженням, почи- наючи із 140-го дня, що підтверджується достовірним зниженням активності супероксиддисмутази і каталази в сироватці крові до кінця експерименту стосовно контролю $(p<0,001)$.

3. При експериментальній неопластичній інтоксикації спостерігають подовження протромбінового часу, скорочення протромбінового індексу, зростання в крові рівня фрібрину А та розчинного фрібрин-мономерного комплексу, що можна розцінювати як передумову патофрізіологічного обґрунтування фрактора ризику активації згортання крові в онкологічних хворих.

\section{СПИСОК ЛІТЕРАТУРИ}

1. Взаимосвязь прогноза выживаемости и повышенного среднего объема тромбоцитов при раке прямой кишки / И. Р. Аглуллин, М. И. Аглуллин, И. А. Комалов [и др.] // Поволж. онкол. весн. - 2018. № 2 (34). - С. 34-39.

2. Ахметзянов Ф.Ш. Ультразвуковая диагностика, тромбообразования у онкологических больных /
Ф. Ш. Ахметзянов, И. А. Комалов // Сибир. онкол. журн. - 2016. - 15, № 5. - С. 60-63.

3. Комалов И. А. Оптимизация диагностики эмболических тромбозов у онкологических больных / И. А. Комалов, И. Р. Аглуллин, М. Г. Тухбатуллин // Казан. мед. журн. - 2013. - 94, № 2. C. 202-207. 
4. Khorana A. A. Venous thromboembolism and prognosis in cancer / A. A. Khorana // Thromb. Res. 2010. - 125, No. 6. - P. 490-493.

5. Pabinger I. Biomarkers for prediction of venous thromboembolism in cancer / I. Pabinger, J. Thaler, C. Ay // Blood. - 2013. - 122, No. 12. - P. 2011-2018.

6 . Rickles F. R. The role of the hemostatic system in tumor growth, metastasis, and angiogenesis: tissue factor is a bifunctional molecule capable of inducing both fibrin deposition and angiogenesis in cancer / F. R. Rickles, M. Shoji, K. Abe // Int. J. Hematol. - 2001. - 73, No. 2. P. $145-150$.

7. Hillen H. F. Thrombosis in cancer patients / H. F. Hillen // Ann. Oncol. - 2000. - 11, Suppl. 3. P. 273-276.

8. Coagulation and cancer: implications for diagnosis and management / M. F. Loreto, M. De Martinis, M. P. Corsi [et al.] // Pathol. Oncol. Res. - 2000. - 6, No. 4. - P. 301-312.

9. Вивчення впливу віку та індексу коморбідності на ризик тромботичних ускладнень у хворих на рак ендометрія на доопераційному етапі / Б. Д. Кривокульський, І. В. Жулкевич, Д. Б. Кривокульський, Л. В. Шкробот // Вісн. наук. дослідж. - 2018. - № 2 (91). - С. 151153.

10. Кривокульський Б. Д. Ризикадаптовані підходи до профрілактики тромботичних ускладнень при гістеректомії / Б. Д. Кривокульський, І.В.Жулкевич // Шпитальна хірургія. Журн. імені Л. Я. Ковальчука. 2018. - № 2 (82). - C. 78-83.

11. European convention for the protection of vertebrate animals used for experimental and other scientific purposes. - Council of Europe, Strasbourg, 1986. - 56 p.

12. Науково-практичні рекомендації з утримання лабораторних тварин та роботи з ними / Ю. М. Ко-

\section{REFERENCES}

1. Aglullin, I.R., Aglullin, M.I., Komalov, I.A., Didakunan, F.I., \& Gabytova, S.Ye. (2018). Vzaymosvyaz prognoza vyzhyvayemosty i povyshennogo srednego obyema trombotsytov pry rake pryamoy kyshki [Interrelation of the prognosis of survival and increased average platelet volume in colorectal cancer]. Povolzhskyi onkologicheskyy vestnik - Volga Oncology Bulletin, 2 (34), 34-39 [in Russian].

2. Akhmetzianov, F.Sh., \& Komalov, Y.A. (2016). Ultrazvukovaya diagnostika, tromboobrazovaniya u onkologicheskykh bolnykh [Ultrasound diagnosis, thrombosis in cancer patients]. Sibirskiy onkologicheskiy zhurnal - Siberian Oncology Journal, 15, 5, 60-63 [in Russian].

3. Komalov, I.A., Aglullin, I.R., \& Tukhbatullin, M.G. (2013). Optymyzatsiya diagnostiky embolicheskykh trombozov u onkologicheskykh bolnykh [Optimization of the diagnosis of embolic thrombosis in cancer patients]. Kazanskyy medytsynskyy zhurnal - Kazan Medical Journal, 94, 2, 202-207 [in Russian].

4. Khorana, A.A. (2010). Venous thromboembolism and prognosis in cancer. Thromb. Res., 125, 6, 490-493. жем'якін, О. С. Хромов, М. А. Філоненко, Г. А. Сайфетдінова. - К. : Авіцена, 2002. - 156 с.

13. Дерягина В. П. Экспериментальное изучение действия (Шиитаке) на рост опухоли у мышей на моделях трансплантационного и химического канцерогенеза / В. А. Дерягина, Н. И. Рыжова, А. Н. Разин // Росс. онкол. журн. - 2009. - № 1. - С. 33-38.

14. Методическое пособие по изучению процессов перекисного окисления липидов и системы антиоксидантной защиты организма животных / [B. С. Бузлама, М. И. Рецкий, Н. П. Мещеряков и др.]. -Воронеж, 1997. -35 c.

15. Колесова О. Е. Перекисное окисление липидов и методы определения продуктов липопероксидации в биологических средах / О. Е. Колесова, А. А. Маркин, Т. Н. Федорова // Лаб. дело. - 1984. № 9. - C. 540-546.

16. Габриэлян Н. И. Скрининговый метод определения средних молекул в биологических жидкостях : метод. рек. / Н. И. Габриэлян, Э. Р. Левицкий, А. А. Дмитриев. - М., 1985. - 22 с.

17. Попов Т. Метод определения пероксидазной активности крови / Т. Попов, Л. Нейковска // Гигиена и санитария. - 1971. - № 10. - С. 89-93.

18. Королюк М. А. Метод определения активности каталазы / М. А. Королюк, Л. И. Иванова, И. Г. Майорова // Лаб. дело. - 1988. - № 1. - С. 16-18.

19. Николайчик В. В. "Средние молекулы" - образование и способы определения /В.В.Николайчик, В. В. Кирковский, В. М. Маин // Лаб. дело. - 1989. № 8. - С. 31-33.

20. Caveolin-1 Inhibits Expression of Antioxidant Enzymes through Direct Interaction with Nuclear Erythroid 2 p45-related Factor-2 (Nrf2) / W. Li, H. Liu, J. S. Zhou [et al.] // J. Biol. Chem. -2012. - 287, No. 25. - P. 2092220930.

5. Pabinger, I., Thaler, J., \&Ay, C. (2013). Biomarkers for prediction of venous thromboembolism in cancer. Blood., 122, 12, $2011-2018$.

6. Rickles, F.R., Shoji, M., \& Abe, K. (2001). The role of the hemostatic system in tumor growth, metastasis, and angiogenesis: tissue factor is a bifunctional molecule capable of inducing both fibrin deposition and angiogenesis in cancer. Int. J. Hematol., 73, 2, 145-150.

7. Hillen, H.F. (2000). Thrombosis in cancer patients. Ann. Oncol., 11, 3, 273-276.

8. Falanga, A,, Marchetti, M,, \& Vignoli, A. (2000). Coagulation and cancer: implications for diagnosis and management. Pathol. Oncol. Res., 6, 4, 301-312.

9. Kryvokulskyi, B.D., Zhulkevych, I.V., Kryvokulskyi, D.B., \& Shkrobot, L.V. (2018). Vyvchennia vplyvu viku ta indeksu komorbidnosti na ryzyk trombotychnykh uskladnen u khvorykh na rak endometriia na dooperatsiinomu etapi [The study of the effect of age and comorbidity index on the risk of thrombotic complications in patients with endometrial cancer at the preoperative stage]. Visnyk naukovykh doslidzhen - Bulletin of Scientific Research, 2 (91), 151-153 [in Ukrainian]. 
10. Kryvokulskyi, B.D., \& Zhulkevych, I.V. (2018). Ryzyk adaptovani pidkhody do profilaktyky trombotychnykh uskladnen pry histerektomii [Risk-adapted approaches to the prevention of thrombotic complications in hysterectomy]. Shpytalna khirurhiia. Zhurnal imeni L. Ya. Kovalchuka - Hospital Surgery. Journal named after L. Ya. Kovalchuk, 2 (82), 78-83 [in Ukrainian].

11. (1986). European Convention for the Protection of Vertebrate Animals Used for Experimental and Other Scientific Purposes. Council of Europe, Strasbourg.

12. Kozhemiakin, Yu.M., Khromov, O.S., Filonenko, M.A., \& Sayfetdinova, G.A. (2002). Naukovo-praktychni rekomendatsii z utrymannia laboratornykh tvaryn ta roboty z nymy [Scientific and practical recommendations for clever laboratory creatures and work with them]. Kyiv: Avitsena [in Ukrainian].

13. Deryagina, V.P., Ryzhova, N.I., \& Razyn, A.N. (2009). Eksperymentalnoe izuchenye deystviya (Shyytake) na rost opukholi u myshey na modelyakh transplantatsyonnogo i khimicheskogo kantserogeneza [An experimental study of the effect (Shiitake) on tumor growth in mice on models of transplantation and chemical carcinogenesis]. Rossyiskiy onkologicheskyy zhurnal Russian Oncological Journal, 1, 33-38 [in Russian].

14. Buzlama, B.C., Retskiy, M.I., Meshcheryakov, N.P., \& Rogacheva, T.Ye. (1997). Metodycheskoe posobye po yzucheniyu protsessov perekysnogo okysleniya lipidov i systemy antyoksydantnoy zashchity organizma zhyvotnykh [Methodological study of lipid peroxidation processes and the antioxidant defense system of animals]. Voronezh [in Russian].
15. Kolesova, O.E., Markyn, A.A., \& Fedorova, T.N. (1984). Perekysnoe okysleniye lipidov i metody opredeleniya produktov lipoperoksydatsii $v$ biologicheskykh sredakh [Lipid peroxidation and methods for determining the products of lipid peroxidation in biological environments]. Laboratornoe delo - Laboratory Matter, 9, 540546 [in Russian].

16. Gabryelyan, N.Y., Levytskyy, E.R., \& Dmytryev, A.A. (1985). Skryningovyy metod opredeleniya srednykh molekul v biologicheskykh zhydkostyakh: Metodicheskiye rekomendatsii [The screening method for determining medium molecules in biological fluids: Methodological recommendations]. Moscow [in Russian].

17. Popov, T., \& Neykovska, L. (1971). Metod opredeleniya peroksydaznoy aktivnosti krovi [Method for determination of peroxidase activity of blood]. Gigiyena i sanitariya - Hygiene and Sanitation, 10, 89-93 [in Russian].

18. Korolyuk, M.A., Ivanova, L.I., \& Mayorova, I.G. (1988). Metod opredeleniya aktivnosti katalazy [Method for determining the activity of catalase]. Laboratornoe delo - Laboratory Matter, 1, 16-18 [in Russian].

19. Nikolaychik, V.V., Kyrkovskiy, V.V., \& Mayn V.M. (1989). "Srednye molekuly" - obrazovaniye i sposoby opredeleniya ["Medium molecules" - formation and methods of determination]. Laboratornoe delo - Laboratory Matter, 8б 31-33 [in Russian].

20. Li, W., Liu, H., Zhou, J.S., Cao, J.F., Zhou, X.B., Choi, A.M., ..., \& Shen, H.H. (2012). Caveolin-1 Inhibits Expression of Antioxidant Enzymes through Direct Interaction with Nuclear Erythroid 2 p45-related Factor-2 (Nrf2). J. Biol. Chem., 287, 25, 20922-20930.

\section{ОЦЕНКА БИОХИМИЧЕСКИХ ПОКАЗАТЕЛЕЙ И СОСТОЯНИЯ СВЕРТЫВАЮЩЕЙ СИСТЕМЫ КРОВИ КРЫС В УСЛОВИЯХ ХРОНИЧЕСКОЙ НЕОПЛАСТИЧЕСКОЙ ИНТОКСИКАЦИИ}

\section{Резюме}

Вступление. Онкологических больных относят к группе высокого риска развития тромбоэмболических и других тяжелых осложнений, что можно объяснить прогрессированием опухоли и действием цитостатических препаратов из-за нарушения как биохимических, так и гемостазиологических процессов. Особое значение при этом имеет эндогенная интоксикация организма.

Цель исследования - оценить биохимические показатели и состояние свертывающей системы крови крыс в условиях хронической неопластической интоксикации.

Методы исследования. Эксперимент выполнен на 36-ти половозрелых нелинейных крысах. Хроническую неопластическую интоксикацию моделировали путем введения несимметричного 1,2-диметилгидразин гидрохлорида (ДМГ) подкожно в межлопаточную область в дозе 7,2 мг/кг 1 раз в неделю в течение 30-ти недель, согласно массы животного - из расчета 0,1 мл раствора ДМГ на 10 г массы тела крысы. Исследование гемостазиологического состояния плазмы крови включало определение протромбинового времени по Квику, протромбинового индекса, активированного частичного тромбопластинового времени, фрибриногена А и фрибрин-мономерного комплекса.

Результаты и обсуждение. Согласно результатам анализа биохимических показателей перекисного окисления липидов и антиоксидантной защиты, на 70-й день эксперимента отмечено лишь тенденцию к росту по сравнению с контрольными данными. На 140-й и 210-й дни выявлено достоверное их повышение относительно контрольной группы. Определение содержания в сыворотке крови крыс моле- 
кул средней массы фракций, которые определялись при длине волны 254 и 280 нм, в разные сроки наблюдения показало статистически достоверное увеличение. Отмечено несущественный рост активированного частичного протромбинового времени в течение всего эксперимента. Относительно других показателей зарегистрировано волнообразные изменения гемостазиологических показателей.

Выводы. В течение 210-ти дней эксперимента нарастают проявления эндогенной интоксикации, о чем свидетельствует достоверное повышение уровня в крови молекул средней массы. Избыточное образование продуктов свободнорадикального окисления в сочетании с компенсаторной активацией энзимных звеньев антиоксидантной системы в начальный период эксперимента и постепенным ее истощением, начиная с 140-го дня, подтверждается достоверным снижением активности супероксиддисмутазы и каталазы в сыворотке крови к концу эксперимента относительно контроля. Удлинение протромбинового времени, сокращение протромбинового индекса, рост в крови уровня фрибриногена $A$ и растворимого фрибрин-мономерного комплекса можно расценивать как предпосылку патофизиологического обоснования фрактора риска активации свертывания крови у онкологических больных.

КЛЮЧЕВЫЕ СЛОВА: экспериментальная хроническая неопластическая интоксикация; перекисное окисление липидов; эндогенная интоксикация; свертывающая система крови.

P. Ya. Bodnar, N. Ye. Lisnychuk

I. HORBACHEVSKY TERNOPIL NATIONAL MEDICAL UNIVERSITY

\title{
ASSESSMENT OF BIOCHEMICAL INDICES AND CONDITION OF COAGULATED BLOOD SYSTEM IN CHRONIC NEOPLASTIC INTOXICATION
}

\begin{abstract}
Summary
Introduction. Oncological patients are at high risk of developing thromboembolic complications and other serious complications, which is explained by the progression of the tumor and the action of cytostatic drugs due to disturbance of both biochemical and hemostatic processes. Of particular importance is the endogenous intoxication of the body.

The aim of the study - to evaluate the biochemical parameters and the state of blood coagulation in rats under chronic neoplastic intoxication.

Research Methods. The experiment was performed on 36 non-linear adult rats. Chronic neoplastic intoxication was modeled by the introduction of asymmetric 1,2-dimethylhydrazine hydrochloride subcutaneously into the intercapillary area at a dose of $7.2 \mathrm{mg} / \mathrm{kg}$ once a week for 30 weeks, according to the animal's weight at the rate of $0.1 \mathrm{ml}$ of DMH solution per 10 grams of body weight of a rat. The study of the hemostatic state of blood plasma included determination of prothrombin time by Quic, prothrombin index, activated partial thromboplastin time, fibrinogen A and fibrin-monomer complex

Results and Discussion. According to the results of the analysis of biochemical parameters of lipid peroxidation on the $70^{\text {th }}$ day of the experiment, there was only a tendency to increase compared to control data. On the $140^{\text {th }}$ and $210^{\text {th }}$ days, their significant increase relative to the control group was revealed. Determination of the content of medium-weight molecules in the blood serum of rats at a wavelength of 254 and $280 \mathrm{~nm}$ during observation showed a statistically significant increase. An insignificant increase in activated partial prothrombin was observed during the entire experiment. Relative to other indicators, wave-like changes in hemostasiological parameters were recorded.

Conclusions. During 210 days of the experiment, manifestations of endogenous intoxication increase, as evidenced by a probable increase in the level of blood in the molecules of medium weight (MSM/254 and MSM/ 280). Excessive formation of products of free radical oxidation in combination with the compensatory activation of the enzyme units of the antioxidant system in the initial period of the experiment and its gradual depletion from 140 days, which is confirmed by a significant decrease in the activity of superoxide dismutase and catalase in the blood serum to the end of the experiment regarding the control. Prothrombin time lengthening, prothrombin index reduction, increase in fibrinogen $A$ and soluble fibrin-monomer complex in the blood, which can be considered as a prerequisite for pathophysiological justification of the risk factor for blood coagulation activation in cancer patients.
\end{abstract}

KEY WORDS: experimental chronic neoplastic intoxication; lipid peroxidation; endogenous intoxication; blood coagulation.

Отримано 15.10.19

Адреса для листування: П. Я. Боднар, Тернопільський національний медичний університет імені І. Я. Горбачевського МОз України, майдан Волі, 1, Тернопіль, 46001, Україна, e-mail: bodnarpj@tdmu.edu.uа 